Economics Development Anaysis Journal 5(2)(2016)

\title{
Analisis Determinan Pangsa Pasar Bank Syariah dengan Kinerja Bank Syariah di Indonesia Periode 2011-2016
}

\section{Sani Noor Rohman ${ }^{1 凶}$, Karsinah²}

Ekonomi Pembangunan, Fakultas Ekonomi, Universitas Negeri Semarang

\begin{tabular}{|c|c|}
\hline Info Artikel & Abstrak \\
\hline $\begin{array}{l}\text { Sejarah Artikel } \\
\text { Diterima Januari } 2016 \\
\text { Disetujui Maret } 2016 \\
\text { Dipublikasikan Mei } 2016\end{array}$ & $\begin{array}{l}\text { Tujuan penelitian ini adalah melihat respon guncangan, dan kontribusi kinerja bank syariah dengan } \\
\text { pangsa pasar. Program Akselerasi Pengembangan Perbankan Syariah (PAPBS) Indonesia } \\
\text { menargetkan pangsa pasar bank syariah pada tahun } 2008 \text { adalah sebesar } 5 \% \text {. Sedangkan pada tahun } \\
2015 \text { mencapai pangsa pasar perbankan syariah sebesar } 15 \% \text {. Namun pada akhir tahun } 2016 \text { pangsa } \\
\text { pasar masih berada pada } 5,29 \% \text {. Variabel penelitianya adalah Market Share (Pangsa Pasar) dengan }\end{array}$ \\
\hline $\begin{array}{l}\text { Kata Kunci: } \\
\text { Market Share, BOPO, CAR, } \\
\text { ROA, FDR, NPF }\end{array}$ & $\begin{array}{l}\text { Biaya Operasional dan Pembiayaan Operasional (BOPO), Capital Adequacy Ratio (CAR), Return } \\
\text { Of Asset (ROA), Finance To Deposte Ratio (FDR), Non Performing Finance (NPF). Hasil analisis } \\
\text { penelitian ini, Kinerja bank syariah menunjukkan Pangsa pasar bank syariah merespon positif } \\
\text { terhadap varaiabel BOPO, CAR, ROA dan FDR, sedangkan variabel NPF merespon negatif, } \\
\text { sedangkan uji Variance Decomposition variabel ROA memiliki kontribusi lebih besar dibandngkan } \\
\text { Variabel BOPO, CAR, FDR,dan NPF. }\end{array}$ \\
\hline
\end{tabular}

\begin{abstract}
The purpose of this research is to see the relationship, shock response, and contribution of syariah bank performance with market share. The Indonesia Islamic Banking Development Acceleration Program (PAPBS) targets the market share of shariah banks in 2008 amounted to 5\%. While in the year 2015 is to achieve sharia banking market share of 15\%. But by the end of 2016 the market share is still at $5.29 \%$. The research variables are Market Share with Operational Cost and Operational Financing (BOPO), Capital Adiquacy Ratio (CAR), Return Of Assets (ROA), Finance To Deposte Ratio (FDR), Non Performing Finance (NPF). The method used VAR (Vector Auto Regretion) which theoretically does not occur relationship between variables with VAR In Difference model.. Result of research is The performance of shariah banks shows that the market share of shariah banks responds positively to BOPO, CAR, ROA and FDR variables, whereas NPF variable responds negatively, while the Variance Decomposition variable of ROA has bigger contribution than BOPO, CAR, FDR, and NPF variables.
\end{abstract}

(C) 2016, Universitas Negeri Semarang

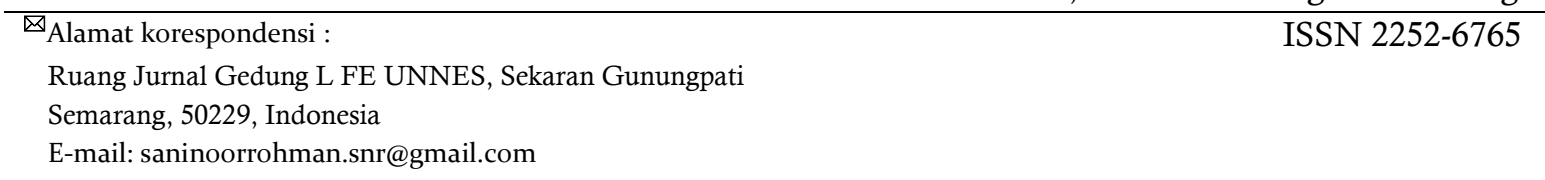




\section{PENDAHULUAN}

Industri perbankan syariah merupakan bagian dari sistem perbankan nasional yang mempunyai peranan sangat penting dalam perekonomian. Peranan perbankan syariah secara khusus antara lain sebagai perekat nasionalisme baru, artinya menjadi fasilitator jaringan usaha ekonomi kerakyatan, mendorong pemerataan pendapatan, dan peningkatan efisiensi mobilitas dana (Saputra, 2014:124). Pentingnya perbankan syariah bagi perkembangan perekonomian diharapkan akan menjadi salah satu ujung tombak bagi kestabilan perekonomian di Indonesia.

Undang-Undang No. 21 pasal 68 Tahun 2008 mengenai perbankan syariah telah disahkan yang mengatur pemisahan, dimana Bank Umum Konvensional (BUK) memiliki Unit Usaha Syariah (UUS) nilai asetnya paling sedikit 50\% (lima puluh persen) dari nilai total aset bank induknya atau 15 tahun sejak berlakunya undangundang ini, maka bank umum konvensional dimaksud wajib melakukan pemisahan.

Bank dikatakan sehat atau tidak, dapat diukur melalui kinerja keuangan perbankan dalam laporan keuangan. Surat edaran BI No.9/24 DPbs disebutkan penilaian tingkat kesehatan bank dipengaruhi oleh faktor CAMEL (Capital, Asset Quality, Manajement, Earning, Liquidity). Aspek Capital meliputi Kewajiban Penyediaan Modal Minimum (KPMM) atau Capital Adequacy Ratio (CAR), aspek Assets meliputi Non Performing Finance (NPF), aspek Earning meliputi Return On Asset (ROE), Return On Asset (ROA), Operational Efficiency Ratio (BOPO), dan aspek Liquidiy meliputi Finance To Deposte Ratio (FDR).

Pangsa pasar dapat digunakan sebagai ukuran kinerja perbankan syariah yang terbilang baru di Indonesia, semakin besar market Pangsa Pasar bank syariah maka semakin besar pula peran dan fungsinya bagi perekonomian nasional (Saputra, 2014:124). Tujuan pangsa pasar sangat menonjol di banyak industri, terutama di mana para manajer sangat memperhatikan peringkat
(Ritz, 2008). Berikut adalah tabel perkembangan komposisi kinerja keuangan dalam laporan

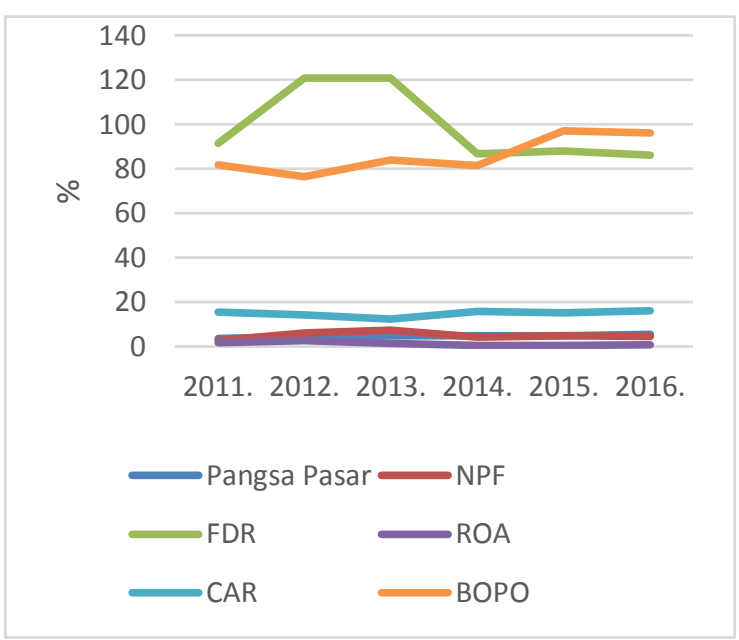

keuangan seperti BOPO, CAR, ROA, FDR, NPF dan Pangsa Pasar pada tahun 2011-2016:

Gambar 1. Komposisi BOPO, CAR, ROA, FDR, NPF dan Pangsa Pasar pada tahun 2011-2016

Gambar 1 menjelaskan bahwa BOPO, CAR, ROA, FDR, NPF dan pangsa pasar mengalami kenaikan dari tahun ketahun dalam kurun waktu 2011-2016, tercermin dalam BOPO bank syariah paling tinggi terjadi tahun 2015 dengan penambahan Biaya operasional \& Pembiayaan Operasional sebesar 15,69\%.. CAR bank syariah paling tinggi terjadi tahun 2014 dengan penambahan sebesar 3,42\%. ROA bank syariah paling tinggi terjadi tahun 2016 dengan penambahan sebesar $0,14 \%$. FDR bank syariah paling tinggi terjadi tahun 2012 dengan penambahan sebesar $29,55 \%$. NPF bank syariah paling tinggi terjadi tahun 2012 dengan penambahan sebesar 3,63\%.

Penambahan pangsa pasar bank syariah paling tinggi terjadi tahun 2012 mencapai 0,95\%, sedangkan penambahan pangsa pasar bank syariah paling rendah pada tahun 2013 mencapai $0,13 \%$. Hipotesis sementara bahwa pangsa pasar bank syariah berkaitan dengan kinerja bank syariah, hal tersebut membuktikan bahwa pertumbuhan perbankan syariah semakin meningkat. Perilaku ekonomi bank asing dan menunjukkan bahwa budaya nasional sama 
pentingnya dengan kondisi pasar kredit dalam menentukan pangsa pasar (Xue \& We, 2013)

Bank Indonesia mengadakan program percepatan pertumbuhan perbankan syariah yaitu melalui Program Akselerasi Pengembangan Perbankan Syariah (PAPBS) sebagaimana dituang dalam cetak biru perbankan syariah Bank Indonesia menargetkan pangsa pasar bank syariah pada tahun 2008 adalah sebesar $5 \%$. Sedangkan nantinya pada tahun 2015 adalah mencapai pangsa pasar perbankan syariah sebesar $15 \%$. Perkembangan perbankan syariah Indonesia sampai dengan Desember 2012 sebesar 4,3\%, di akhir tahun 2014, perkembangan market Pangsa Pasar bank syariah $4,88 \%$, sedangkan pada akhir tahun 2015 ternyata naik kembali menjadi 4,87 , sampai pada tahun 2016 pangsa pasar bank syariah masih 5,29 $\%$. Tujuan penelitian ini adalah melihat respon guncangan, dan kontribusi kinerja bank syariah dengan pangsa pasar. Jika perusahaan kecil bisa melakukan inovasi lebih efisien, maka melindungi perusahaan kecil melalui regulasi pangsa pasar dapat meningkatkan kesejahteraan sosial (Konishi \& Çaglar, 2014)

\section{METODE PENELITIAN}

. Analisis yang digunakan menggunakan metode VAR (Vector Auto Regression) yang secara teoritis tidak terjadi hubungan antar variabel dengan model VAR In Difference. Data penelitian ini didapat dari statistik perbankan syariah yang dipublikasikan OJK, dan data dari Bank Indonesia. Periode penelitian yaitu tahun 20112016. Uji yang dilakukan dalam analisis VAR meliputi uji akar unit (Unit Root Test), uji panjang lag optimal, uji Kointegrasi (Johansen's Cointegration Test), uji kausalitas grangger Uji intinya adalah Impulse Response Function (IRF) digunakan melacak respon dari variabel endogen di dalam sistem VAR karena adanya goncangan (shock) atau perubahan di dalam variabel gangguan dan analisis Variance Decomposition dan berguna untuk memprediksi kontribusi persentase varian setiap variabel karena adanya perubahan variabel tertentu di dalam sistem VAR.

$$
\begin{aligned}
& \text { 1. } P P_{t}=\alpha_{1 i}+\beta_{1} R O A_{t-i}+\beta_{2} C A R_{t-i}+ \\
& \beta_{3} F D R_{t-i}+ \\
& \beta_{4} N P F_{t-i} \beta_{5} B O P O_{t-i}+\varepsilon_{t} \ldots .(1) \\
& \text { 2. } R O A_{t}=\alpha_{2 i}+\beta_{1} P P_{t-i}+\beta_{2} F D R_{t-i}+ \\
& \beta_{3} N P F_{t-i}+\beta_{4} B O P O_{t-i}+ \\
& \beta_{5} C A R_{t-i}+\varepsilon_{t} \\
& \text { 3. } C A R_{t}=\alpha_{3 i}+\beta_{1} R O A_{t-i}+\beta_{2} F D R_{t-i}+ \\
& \beta_{3} N P F_{t-i}+\beta_{4} B O P O_{t-i}+ \\
& \beta_{5} P P_{t-i}+\varepsilon_{t} \\
& \text { 4. } F D R_{t}=\alpha_{4 i}+\beta_{1} N P F_{t-i}+\beta_{2} B O P O_{t-i}+ \\
& \beta_{3} P P_{t-i}+\beta_{4} R O A_{t-i}+\beta_{5} C A R_{t-i}+ \\
& \varepsilon_{t} \ldots \ldots \ldots \ldots \ldots \ldots \ldots \ldots \ldots \ldots \ldots \ldots \ldots .(4) \\
& \text { 5. } N P F_{t}=\alpha_{5 i}+\beta_{1} B O P O_{t-i}+\beta_{2} P P_{t-i}+ \\
& \beta_{3} R O A_{t-i}+\beta_{4} C A R_{t-i}+\beta_{5} F D R_{t-i}+
\end{aligned}
$$

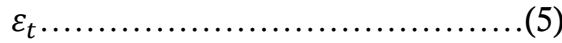

$$
\begin{aligned}
& \text { 6. } B O P O_{t}=\alpha_{6 i}+\beta_{1} P P_{t-i}+\beta_{2} R O A_{t-i}+ \\
& \beta_{3} C A R_{t-i}+\beta_{4} F D R_{t-i}+ \\
& \beta_{5} N P F_{t-i}
\end{aligned}
$$

\section{Keterangan:}

$P P_{t} \quad=$ Pangsa pasar pada tahun $\mathrm{t}$

$B O P O_{t}=$ BOPO pada tahun $\mathrm{t}$

$C A R_{t} \quad=$ CAR pada tahun $\mathrm{t}$

$R O A_{t}=$ ROA pada tahun $\mathrm{t}$

$F D R_{t} \quad=$ FDR pada tahun $\mathrm{t}$

$N P F_{t} \quad=$ NPF pada tahun $\mathrm{t}$

$P P_{t-i} \quad=$ Pangsa pasar pada tahun $\mathrm{t}-\mathrm{n}$

$B O P O_{t-i}=$ BOPO pada tahun $\mathrm{t}-\mathrm{n}$

$C A R_{t-i}=$ CAR pada tahun $\mathrm{t}-\mathrm{n}$

$R O A_{t-i}=$ ROA pada tahun $\mathrm{t}-\mathrm{n}$

$F D R_{t-i}=$ FDR pada tahun $\mathrm{t}-\mathrm{n}$

$N P F_{t-i}=\mathrm{NPF}$ pada tahun $\mathrm{t}-\mathrm{n}$

$\alpha_{1 \mathrm{i},}, \alpha_{6 \mathrm{i}}=$ konstanta

$\beta_{1-} \beta_{5} \quad=$ koefisien

$\varepsilon_{t} \quad=$ faktor gangguan

Hipoteisis

H1 : Variabel kinerja bank syariah yaitu BOPO merespon negatif perubahan yang terjadi pangsa pasar bank syariah

H2 : Variabel kinerja bank syariah yaitu CAR merespon positif perubahan yang terjadi pada pangsa pasar bank syariah

H3 : Variabel kinerja bank syariah yaitu ROA merespon positif perubahan yang terjadi pada pangsa pasar bank syariah 
H4 : Variabel kinerja bank syariah yaitu FDR merespon positif perubahan yang terjadi pada pangsa pasar bank syariah

H5 : Variabel kinerja bank syariah yaitu NPF merespon negatif perubahan yang terjadi pada pangsa pasar bank syariah

H6 : Variabel kinerja bank syariah yaitu yaitu BOPO, CAR, ROA, FDR, dan NPF berkontribusi terhadap perubahan pangsa pasar bank syariah

\section{HASIL DAN PEMBAHASAN}

Analisis Impulse Response Function (IRF), Berfungsi untuk melacak respon dari variabel endogen di dalam sistem VAR karena adanya goncangan (shock) atau perubahan di dalam variabel gangguan. Berikut hasil analisis IRF yang dintunjukkan pada Tabel 1 dan gambar 2:

Tabel 1. Hasil Selisih Pangsa Pasar dengan BOPO, CAR, ROA, FDR, dan NPF

\begin{tabular}{|c|c|c|c|c|c|c|}
\hline & BOP0 & CAR & ROA & FDR & NPF & $\begin{array}{l}\text { Pangsa } \\
\text { Pasar }\end{array}$ \\
\hline \begin{tabular}{|l|} 
Selisih \\
Periode \\
\end{tabular} & -0.011248 & -0.013154 & -0.01574 & -0.008879 & 0.029088 & -0.063541 \\
\hline \begin{tabular}{|l|} 
Respon \\
Tertinggi \\
\end{tabular} & 0.014916 & 0.021392 & 0.029370 & 0.018443 & -0.031373 & 0.093644 \\
\hline \begin{tabular}{|l|} 
Respon \\
Terendah \\
\end{tabular} & 0.003668 & 0.006755 & 0.012277 & 0.005151 & -0.002285 & 0.030103 \\
\hline
\end{tabular}

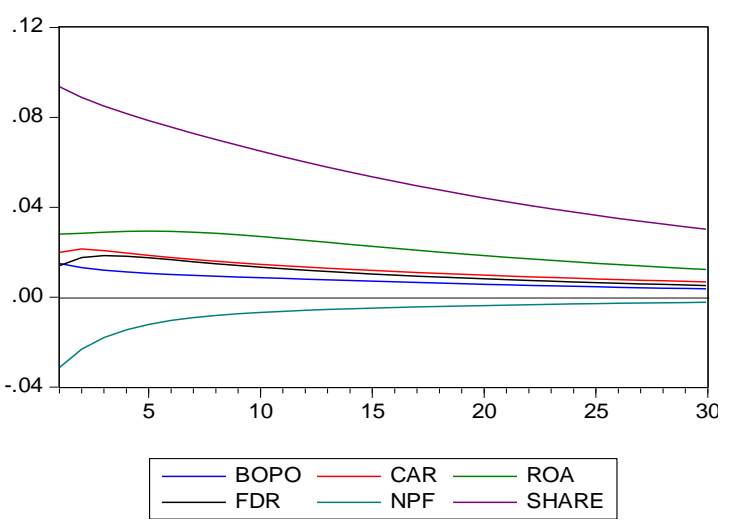

Gambar 2. response of SHARE to Cholesky One S.D Innovations

Berdasarkan tabel 1 dapat diketahui bahwa awal periode BOPO memberikan respon positif pada Pangsa Pasar. Pada periode selanjutnya terjadi penurunan respon, hingga mencapai respon positif dan puncak positif tertinggi terjadi pada periode ke-1 ( $0.014 \%)$. Kecenderungan BOPO mengalami penurunan dari awal periode hingga periode tigapuluh sebesar $-0.011 \%$. Perkembangan IRF tersebut menjelaskan gejolak respon yang semakin mengecil namun respon tersebut tidak sepenuhnya menghilang tetapi tetap bergerak dalam fluktuasi positif. Hal ini menujukkan kenaikkan yang terjadi pada variabel BOPO menjelaskan kemampuan manajemen bank dalam mengendalikan biaya operasional terhadap pendapatan operasional menyebabkan jumlah Pangsa Pasar mengalami kenaikan, begitu juga sebaliknya.

Hasil IRF variabel BOPO terhadap kejutan pangsa pasar ini tidak sesuai dengan hipotesis awal, yaitu variabel BOPO merespon negatif. Hasil penelitian ini respon positif BOPO menunjukkan bahwa semakin besar rasio maka akan semakin besar risiko operasional yang akan ditanggung oleh bank (siamat, 1993:42), sehingga justru pangsa pasar bank syariah mengalami kenaikan. Hal ini tidak sesuai dengan penelitian (Aulia Rahman, 2016:300) apabila BOPO dapat dikendalikan oleh bank syariah, maka Pangsa Pasar bank syariah diprediksi akan meningkat.

CAR pada awal periode sampai periode tiga memberikan respon negatif terhadap Pangsa Pasar dengan standar deviasi awal mula sebesar $0.019 \%$. Periode selanjutnya terjadi penurunan respon, hingga mencapai respon positif dan puncak positif tertinggi terjadi pada periode ke-2 ( 0.021\%). Kecenderungan CAR mengalami penurunan dari awal periode hingga periode tigapuluh sebesar $-0.013 \%$. Selanjutnya dalam jangka panjang respon tetap pada posisi positif namun tidak menuju keseimbangan (konvergen). Artinya bahwa pada periode empat sampai periode tigapuluh, terjadi penurunan variabel CAR menjelaskan kecukupan modal yang berfungsi menghimpun risiko kerugian yang dihadapi oleh bank menyebabkan pangsa pasar bank syariah juga mengalami penurunan. 
Hasil IRF variabel CAR terhadap kejutan pangsa pasar ini sesuai dengan hipotesis awal, yaitu merespon positif perubahan yang terjadi pangsa pasar. Hasil penelitian ini tidak selaras dengan penelitian (hakiim, 2016:167) Tidak berpengaruhnya CAR terhadap ROA (asset) sebagai proyeksi pangsa pasar bank syariah disebabkan karena bank-bank yang beroperasi tidak mengoptimalkan modal yang ada, Hal ini terjadi karena peraturan Bank Indonesia, mengakibatkan bank-bank selalu berusaha menjaga agar CAR yang dimilikinya. Pada penelitian Saputra 2014 variabel CAR berpengaruh positif terhadap pangsa pasar bank syariah, sesuai dengan peneltian ini.

Hasil kesimpulan uji IRF menunjukkan respon negatif variabel ROA terhadap Pangsa Pasar. Pada periode pertama sampai periode enam mengalami kenaikan standar deviasi dari $0.028 \%$, menjadi $0.029 \%$, Pada periode selanjutnya terjadi penurunan respon, hingga mencapai respon positif dan puncak positif tertinggi terjadi pada periode ke-5 (0.029\%). Kecenderungan ROA mengalami penurunan dari awal periode hingga periode tigapuluh sebesar $-0.015 \%$. Artinya bahwa terjadi penurunan variabel ROA menunjukkan rasio antara laba sebelum pajak terhadap total asset menyebabkan pangsa pasar bank syariah juga mengalami penurunan. Kemudian dalam jangka panjang respon berfluktuatif dan menunjukkan respon postif tidak mendekati keseimbangan (konvergen) namun tidak menghilang.

Hasil IRF variabel ROA terhadap kejutan pangsa pasar ini sesuai dengan hipotesis awal, yaitu merespon positif perubahan yang terjadi pangsa pasar. Teori ROA menjelaskan bahwa semakin besar ROA suatu bank, maka semakin besar pula tingkat keuntungan yang dicapai dan semakin baik posisi bank tersebut dari segi penggunaan aset, semakin besar ROA suatu bank, semakin besar pula pula posisi bank tersebut dari segi penggunaan aset (Dendawijaya, 2003:120), sehingga apabila profitabilitas suatu bank tersebut memiliki peningkatan yang signifikan maka masyarakat akan mempercayakan untuk menempatkan dananya di bank tersebut karena masyarakat akan memperhitungkan bagi hasil yang diperolehnya akan cukup menguntungkan baginya, oleh karena itu karena semakin besar ROA suatu bank, semakin besar pula tingkat keuntungan yang dicapai bank, dan semakin baik kinerja dan posisi pangsa pasar bank tersebut. Hasil penelitian ini tidak selaras dengan penelitian oleh Dr.Khaled Subhi Rajha,dan Dr. Zaher Abdel Fattah Alslehat (2014) menganalisis index Hervindal sebagai proyeksi pangsa pasar yang mempunyai pengaruh negatif terhadap ROA, namun pada penelitian Obeidat,dkk (2013) Pangsa Pasar berpengaruh positif terhadap profitabilitas (ROA).

Variabel FDR pada periode awal standar deviasi sebesar $0.014 \%$, Selanjutnya FDR mengalami perubahan yang relatif stabil dan menurun. Periode kedua memberikan respon negatif pada pangsa pasar bank syariah sebesar $0.017 \%$. Pada periode selanjutnya terjadi penurunan respon, hingga mencapai respon positif dan puncak positif tertinggi terjadi pada periode ke-4 (0.018\%). Kecenderungan FDR mengalami penurunan dari awal periode hingga periode tigapuluh sebesar $-0.008 \%$.Menunjukkan bahwa pada periode kedua sampai tiga sepuluh, semakin FDR mengalami penurunan, diikuti dengan menurunya pangsa pangsa bank syariah. Kemudian dalam jangka panjang respon berfluktuatif dan menunjukkan respon positif mendekati keseimbangan (konvergen) namun tidak menghilang

Hasil IRF variabel FDR terhadap kejutan pangsa pasar ini sesuai dengan hipotesis awal, merespon positif perubahan yang terjadi pangsa pasar. Berdasarkan teori yang sudah dijelaskan sebelumnya, variabel FDR merupakan rasio pembiayaan terhadap dana pihak ketiga yang menggambarkan sejauh mana simpanan digunakan untuk pemberian pembiayaan yang biasa digunakan untuk mengukur tingkat likuiditas perbankan syariah dengan membandingkan jumlah kredit yang disalurkan dengan jumlah deposit yang dimiliki sehingga rasio pembiayaan meningkat maka semakin banyak dana yang disalurkan dalam bentuk pembiayaan, sehingga akan meningkatkan pangsa pasar bank syariah. 
Penelitian ini sesuai dengan penelitian yang dilakukan (Saputra, 2014:130) menjelaskan pengaruh signifikan dan positif FDR terhadap pangsa pasar, dan penelitian Purboasti (2015) menjelaskan variabel FDR mempengaruhi pangsa pasar perbankan Islam di Indonesia. Namun pada penelitian Hakiim (2016) variabel FDR secara parsial berpengaruh negatif dan tidak signifikan terhadap profitabilitas (proyeksi pangsa pasar).

Periode pertama variabel NPF mempunyai respon negatif terhadap pangsa pasar yaitu sebesar $0.031 \%$. Sering perkembangan periode, variabel NPF mengalami penurunan standar devasi, diawali pada periode ketiga sebesar $0.018 \%$ Pada periode selanjutnya terjadi penurunan respon, hingga mencapai respon negatif dan puncak negatif tertinggi terjadi pada periode ke-1 (-0.031\%). Kecenderungan NPF mengalami penurunan dari awal periode hingga periode tigapuluh sebesar $0.029 \%$.Artinya semakin menurunya variabel NPF, juga diiringi naiknya Pangsa Pasar bank syariah. Kemudian dalam jangka panjang respon berfluktuatif dan menunjukkan respon negatif mendekati keseimbangan (konvergen) namun tidak menghilang.

Hasil IRF variabel NPF terhadap kejutan pangsa pasar ini sesuai dengan hipotesis awal, merespon negatif perubahan yang terjadi pangsa pasar. Teori yang menjelaskan sebelumnya, bahwa NPF menunjukkan kemampuan manajemen bank dalam mengelola pembiayaan bermasalah yang diberikan oleh bank, sehingga semakin tinggi rasio ini maka semakin buruk kualitas kredit bank yang menyebabkan jumlah kredit bermasalah semakin besar maka kemungkinan suatu bank dalam kondisi bermasalah semakin besar. Hasil penelitian Aulia Rahman (2016) dan penelitian Nur Mawaddah (2015) menjelaskan variabel NPF perbengaruh kepada pangsa pasar bank syariah.

Respon positif menunjukkan bahwa goncangan pangsa pasar bank syariah menimbulkan kenaikan tingkat kinerja bank syariah. Sedangkan respon negatif yaitu apabila terjadi kenaikan pangsa pasar maka akan menurunkan tingkat kinerja bank syariah. Respon tertinggi kinerja bank syariah ditunjukkan pada variabel NPF dibandingkan variabel yang lainya, sedangkan variabel $\mathrm{BOPO}$, CAR, FDR dalam mencapai kestabilan terhadap pangsa pasar membutuhkan waktu yang relatif lambat dan stabil. Respon penyesuaian yang lambat ini disebabkan oleh tidak meratanya pembiayaan bank syariah yang didominasi oleh akad Murabahah, dan kurang berkembang akad pembiayaan yang lainya seperti mudharabah, musyarakah, salam, istishna, ijrah, dan qard. Pada dasarnya pembiayaan berdasarkan prinsip syariah merupakan penyediaan uang dan barang dari pihak bank kepada nasabah sesuai kesepakatan yang mewajibkan pihak yang dibiayai untuk mengembalikan uang setelah jangka waktu tertentu dengan imbalan atau bagi hasil, oleh karena itu berimbas pada kinerja bank syariah.

Analisis Variance Decomposition, berfungsi untuk memprediksi kontribusi persentase varian setiap variabel karena adanya perubahan variabel tertentu di dalam sistem VAR. Berikut Hasil Uji Variance Decomposition, yang di tunjukkan pada Gambar 3.

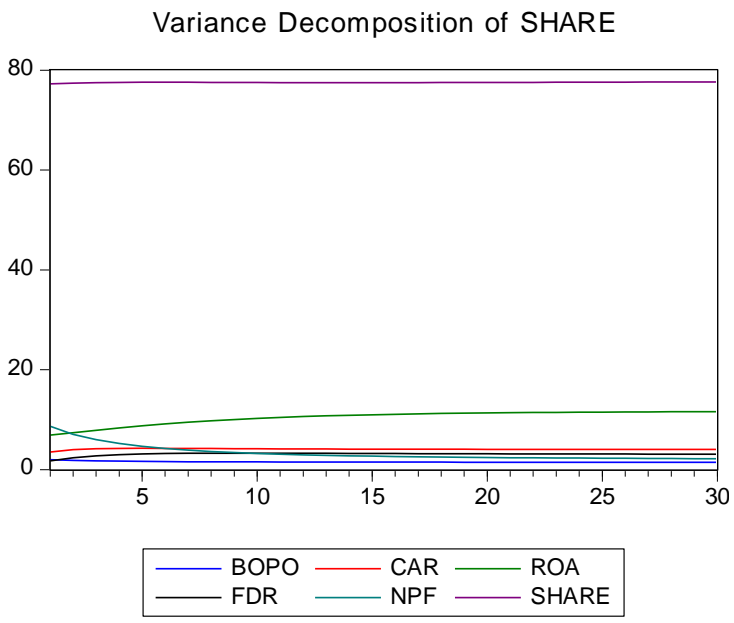

Gambar 3. Variance Decomposition of SHARE

Berdasarkan gambar 3 menunjukkan perkiraan error variance bahwa pada periode pertama dipengaruhi oleh goncangan Pangsa Pasar sebesar $77,23 \%$, selanjutnya diikuti oleh NPF, ROA, CAR, BOPO, FDR sebesar 8.66\%, 
$6.91 \%, 3.49 \%, 1.95 \%, 1.73 \%$. Perkembangan error variance pada periode kedua baru mulai mengalami perkembangan kontribusi antar varaiabel terhadap pangsa pasar. Variabel Pangsa Pasar mempunyai pengaruh terhadap perkiraan error varians sebesar $77,39 \%$, diikuti oleh perubahan kontribusi ROA sebesar 7.38\%, sedangkan kontribusi menurun NPF sebesar $7.05 \%$, CAR sebesar $3.96 \%$, FDR sebesar $2.36 \%$ BOPO sebesar $1.82 \%$.

Pada periode ke enam, fluktuasi pangsa pasar dijelaskan oleh pangsa pasar sebesar $77,56 \%$, ROA sebesar 9,13\%, CAR sebesar $4,24 \%$, NPF sebesar 4,22\%, FDR sebesar 3,21\%, BOPO sebesar $1,60 \%$. Variabel ROA mengalami perkembangan kontribusi yang terus meningkat terhadap pangsa pasar dibandingkan variabel lainya sedangkan kontribusi variabel CAR dengan NPF pada periode enam mencapai angka yang hampir sama, dalam kontribusi terhadap pangsa pasar. Kondisi ini disebabkan ROA sebagai indikator asset perbankan memiliki hubungan dengan pangsa pasar, dalam menentukan besarnya pangsa pasar salahsatunya terdiri dari asset.

Setiap periodenya masing-masing variabel memberikan kontribusi yang berbedabeda terhadap Pangsa Pasar bank syariah sampai periode tigapuluh. Variabel BOPO memberikan kontribusi yang kecil dibandingan variabel yang lain kemudian diikuti variabel NPF yang ditunjukkan pada error variance terus mengalami fluktuasi yang cenderung menurun hingga periode tigapuluh $1,44 \%$ dan $2,18 \%$. Kondisi ini disebabkan variabel BOPO, kurangnya manajemen pengelolan biaya operasional bank syariah.

Secara keseluruhan diperoleh hasil bahwa variabel ROA memberikan kontribusi yang lebih besar dalam menjelaskan variabilitas Pangsa Pasar bila dibandingkan dengan BOPO, ROA, CAR, FDR, NPF yaitu sebesar 11,60\%. Hasil variance decomposition Pangsa Pasar diperoleh hasil bahwa dalam jangka menengah dan jangka panjang kontribusi ROA lebih besar dibandingkan BOPO, CAR, FDR dan NPF.

Hasil Variance Decomposition

menunjukkan bahwa dalam jangka waktu 30 periode kedepan, memiliki hubungan pangsa pasar dengan kinerja bank syariah. Namun kontribusi dan korelasi antar kinerja bank syariah berkontribusi terhadap pangsa pasar hanya didominasi beberapa kinerja saja terutama variabel ROA sebesar $11,60 \%$. Berdasarkan pemaparan hasil penelitian tersebut, kondisi variabel kinerja bank syariah yaitu BOPO, CAR, ROA, FDR, dan NPF menunjukkan bahwa belum adanya kesamaan pola guncangan dan keterkaitan yang kuat dari masing-masing variabel. Selama jangka waktu 30 periode, masih terdapat beberapa variabel yang belum stabil dalam menghadapi perubahan yang terjadi pada pangsa pasar. Kurang maksimalnya hubungan kinerja bank syariah dengan pangsa pasar. Hasil penelitian kontribusi kinerja dengan pangsa pasar selaras dengan pedekatan SCP yang dimana struktur dan perilaku akan memberikan pengaruh pada kinerja, lalu akhirnya akan berpengaruh terhadap laba yang merupakan tujuan utama setiap. Selaras dengan penelitian Rahim dan Zakaria (2013)yang menunjukkan bahwa rata-rata bank syariah relatif lebih stabil dari pada bank konvensional, dengan total assets, Herfindahl Index sebagai proyeksi market Pangsa Pasar, inflasi dan GDP riil, signifikan terhadap stabilitas perbankan dengan proyeksi Z score dan NPL.

\section{SIMPULAN}

Hasil analisis Impulse Respons Function (IRF) terhadap kinerja bank syariah menunjukkan Pangsa pasar bank syariah merespon positif terhadap varaiabel BOPO, CAR, ROA dan FDR, sedangkan variabel NPF merespon negatif. Fluktuasi Pangsa Pasar didominasi dari kondisi pangsa pasar itu sendiri, sedangkan variabel yang menunjukkan dampak dari adanya shock atau perubahan bersifat positif, artinya perubahan naiknya variabel BOPO, 
CAR, ROA dan FDR akan diikuti dengan naiknya pangsa pasar bank syariah.

Hasil analsisi uji Variance Decomposition kinerja bank syariah terhadap pangsa pasar bank syariah. Variabel BOPO, CAR, ROA, FDR, NPF memberikan kontribusi terhadap perubahan pangsa pasar bank syariah yaitu sebesar $1.52 \%, 4.17 \%, 11,60,3.28 \%, 3.23 \%$. Secara keseluruhan diperoleh hasil bahwa variabel ROA memberikan kontribusi yang lebih besar dalam jangka menengah dan jangka panjang menjelaskan variabilitas Pangsa Pasar bila dibandingkan dengan BOPO, ROA, CAR, FDR, dan NPF

\section{DAFTAR PUSTAKA}

Hafidh Ahmad, Aula. 2011. Analisis Hubungan Pengeluaran Pendidikan Dan Pertumbuhan Ekonomi Dengan Menggunakan Pendekatan Kausalitas Granger. Jurnal Ekonomi \& Pendidikan, Volume 8 Nomor 2, November 124-141.

Hamka. 2014. Pengaruh Tingkat Bonus Sertifikat Bank Indonesia Syariah Dan Tingkat Inflasi Terhadap Pembiayaan Bank Syariah Di Indonesia. Universitas Muhammadiyah Prof. Dr. Hamka, 13(2), 104-117.

Kholis, M., Astuti, Diah., Febrianti, Rini. 2016. Hubungan Antara Pendapatan Nasional Dan Investasi Di Indonesia ( Suatu Kajian Ekonomi Makro dengan Model VAR ). Jurnal Organisasi dan Manajemen, Volume 12, Nomor 1.

Konishi, Hideo \& Çaglar Yurtseven, 2014. Market share regulation?. Japan and the World Economy, Volume 29 , Pages 36-45

Nacrowi D, Nacrowi., Usman, Hardius. 2006. Pendekatan Popular dan Praktis Ekonometrika Untuk Analisis Ekonomi dan Keuangan. Jakarta: Lembaga Penerbit Fakultas Ekonomi, Universitas Indonesia. Noverinato, Fajar., Ratnawati, Nirdukita. 2014. Analisis Efektivitas Jalur Pembiayaan Syariah Terhadap Produk Domestik Bruto Usaha Mikro Kecil Dan Menengah Di Indonesia Dengan Metode Var. Jurnal Ekonomi Pembangunan:73, 73-92.
Otoritas Jasa Keuangan. 2010-2016. Statistik Perbankan Syariah. Jakarta : Otoritas Jasa Keuangan. diakses 14 Januari 2017

Ramdani, Andreyanto. 2012. Pengaruh Kebijakan Pemisahan Terhadap Laba Pada Bank Bni Syariah. UIN Jakarta.

Ritz, Robert A. 2008. Strategic incentives for market share. International Journal of Industrial Organization, Volume 26, Issue 2, Pages 586597

Saputra, B.2014. Faktor-Faktor Keuangan Yang Mempengaruhi Market Shar Perbankan Syariah Di Indonesia. Balikpapan, S. M. VII(2), 123-131.

Surat Edaran Bank Umum Yang Melaksanakan Kegiatan Usaha Berdasarkan Prinsip Syariah Di Indonesia No.9/24/DPbS. 30 Oktober 2007 Diakses tanggal 23 Agustus 2017

Undang-Undang No. 21 pasal 68 Tahun 2008 tentang pemisahan Bank Umum Konvensional (BUK) memiliki Unit Usaha Syariah (UUS). diakses 5 Januari 2017

Wahyudin, Agus. 2015. Metodologi Penelitian: Penelitian Bisnis dan Pendidikan. Semarang:Unnes Press.

Widarjono, Agus. 2009. Ekonometrika Pengantar dan Aplikasinya. Yogyakarta: Ekonisia

Xue, Minggao \& Wen Cheng. 2013. National culture, market condition and market share of foreign bank. Economic Modelling, Volume 33, Pages 991-997 